\title{
PENGEMBANGAN LEMBAR KERJA SISWA (LKS) DENGAN PENDEKATAN CONTEXTUAL TEACHING AND LEARNING (CTL) PADA MATERI PENJUMLAHAN DAN PENGURANGAN BENTUK ALJABAR TERKAIT KEARIFAN LOKAL DI KELAS VII SMP NEGERI 6 PEMATANG SIANTAR
}

\author{
${ }^{1}$ Juli Antasari Br Sinaga, ${ }^{2}$ Belsasar Sihombing, ${ }^{3}$ Lovita Sirait \\ ${ }^{1,2}$ Pendidikan Matematika, FKIP Universitas HKBP Nommensen Medan \\ ${ }^{3}$ Pendidikan Matematika, Mahasiswa FKIP Universitas HKBP Nommensen Medan \\ email: julisinaga@uhn.ac.id
}

\begin{abstract}
Abstrak. Penelitian ini bertujuan untuk: 1) mengembangkan produk LKS dengan pendekatan CTL untuk memahami konsep penjumlahan dan pengurangan bentuk aljabar terkait kearifan lokal di kelas VII SMP Negeri 6 Pematangsiantar. 2) mengetahui hasil pengembangan LKS dengan pendekatan CTL untuk memahami konsep penjumlahan dan pengurangan bentuk aljabar terkait kearifan lokal di kelas VII SMP Negeri 6 Pematangsiantar yang valid, praktis dan efektif. Metode yang digunakan dalam penelitian ini adalah metode pengembangan model 4D (Define, Design, Develop, Desseminate). Namun dalam penelitian ini, pengembangan LKS hanya sampai pada tahap develop saja dikarenakan keterbatasan waktu dan dana. Temuan dalam penelitian ini adalah 1) Hasil pengembangan LKS dengan pendekatan CTL pada materi penjumlahan dan pengurangan bentuk aljabar telah valid berdasarkan isi, konstruk, dan bahasa, dengan tingkat kevalidan 4,33 dalam kategori sangat valid. 2) Hasil pengembangan LKS dengan pendekatan CTL pada materi penjumlahan dan pengurangan bentuk aljabar telah praktis dengan tingkat kepraktisan 83,30\% dalam kategori praktis, dan 3) Hasil pengembangan LKS dengan pendekatan CTL pada materi penjumlahan dan pengurangan bentuk aljabar telah efektif berdasarkan hasil tes siswa dengan nilai rata-rata siswa 79 dalam kategori baik.
\end{abstract}

Kata Kunci: Pengembangan LKS, CTL,Kearifan Lokal.

\begin{abstract}
This research ais to: 1) develop LKS products with a CTL approach to understand concepts addition and subtraction of algebra related to local wisdom in class VII SMP Negeri 6 Pematangsiantar. 2) To know the result of LKS development with the CTL approach of understand the concept of adding and reducing algebra related to local wisdom in class VII SMP Negeri 6 Pematangsiantar which is valid, practical, and effective. The method used in this study is the 4D model develepmont method (Define, Design, Develop, Desseminate). But in this study, the development of LKS only reached the stage develop because limited time and funds. The findings in this study are: 1) The result of LKS development with the CTL approach on the material of adding and reducing algebra are valid based on contents, constructs, and language, with a level of validity of 4,33 in the very valid category. 2) The results of developing LKS with a CTL approach on the addition and subtraction of algebra forms have been practical with a practicality level of $83,30 \%$ in the practical category, and 3) The results of developing LKS with a CTL approach on the material of addition and reducing of algebra form have been effective based on student test
\end{abstract}


results with an average score of 79 and student are in the good category.

Keywords: LKS development, CTL, Local Wisdom.

\section{PENDAHULUAN}

Kapal Matematika sebagai salah satu ilmu yang mempunyai peranan sangat penting dalam perkembangan teknologi informasi dan komunikasi yang kian pesat. Untuk menguasai dan mencipta teknologi di masa depan diperlukan penguasaan matematika yang kuat sejak dini. Siswa diharapkan memiliki berbagai kemampuan agar kualitas pembelajaran matematika lebih baik.

Tujuan umum pembelajaran matematika yang dirumuskan dalam Permendiknas Nomor 22 Tahun 2006 tentang Standar Isi, adalah:

siswa memiliki kemampuan: 1) memahami konsep matematika, menjelaskan keterkaitan antar konsep dan mengaplikasikan konsep atau algoritma secara luwes, akurat, efisien, dan tepat dalam pemecahan masalah, 2) menggunakan penalaran pada pola dan sifat, melakukan manipulasi matematika dalam membuat generalisasi, menyusun bukti, atau menjelaskan gagasan dan pernyataan matematika, 3) pemecahan masalah yang meliputi kemampuan memahami masalah, merancang model matematika, menyelesaikan model dan menafsirkan solusi yang diperoleh, 4) mengkomunikasikan gagasan dan simbol, tabel, diagram, atau media lain untuk memperjelas keadaan atau masalah, 5) memiliki sikap menghargai kegunaan matematika dalam kehidupan, yaitu memiliki rasa ingin tahu, perhatian, dan minat dalam mempelajari matematika serta sikap ulet dan percaya diri dalam pemecahan masalah.

Pemahaman konsep merupakan suatu aspek yang sangat penting dalam pembelajaran, karena dengan memahami konsep siswa dapat mengembangkan kemampuannya dalam setiap materi pelajaran. Pemahaman konsep matematika merupakan salah satu kecakapan atau kemahiran siswa yang mampu memanfaatkan atau mengaplikasikan konsep yang telah dipahaminya sehingga dapat diterjemahkan kedalam kegiatan belajar, dan dikaitkan dengan konsep-konsep sebelumnya.

Memahami konsep matematika akan memungkinkan siswa dalam penyelesaian berbagai persoalan dalam mempelajari matematika dan menghubungkan pengetahuan yang dimiliki sebelumnya dengan pengetahuan yang akan dipelajari

Salah satu materi pembelajaran yang perlu dipahami oleh siswa adalah aljabar. Pada kurikulum 2013 kompetensi dasar pembelajaran matematika tentang aljabar yaitu siswa kelas VII SMP diharapkan mampu untuk menjelaskan bentuk aljabar, melakukan operasi penjumlahan dan pengurangan aljabar, serta mampu menyelesaikan masalah yang berkaitan dengan operasi penjumlahan dan pengurangan aljabar. Kemampuan pemahaman konsep dalam materi ini penting bagi siswa karena merupakan dasar untuk memahami operasi hitung aljabar yang akan digunakan dalam berbagai topik pembelajaran lainya, seperti persamaan dan pertidaksamaan linear, aritmatika serta fungsi linear.

Pada kenyataannya kemampuan pemahaman konsep matematika siswa masih rendah terlihat dari penjajakan awal yang peneliti lakukan terhadap 30 siswa kelas VII di SMP Negeri 6 Pematangsiantar, dilakukan dengan memberi soal penjumlahan dan pengurangan aljabar. Soal yang diberikan adalah sebagai berikut.

Tentukan hasil operasi hitung berikut.

$$
\begin{aligned}
& \text { a. }(7 a+4 b)+(8 a+6 b) \\
& \text { b. }(3 x-4 y)-(5 x-6 y)
\end{aligned}
$$

Hasil penjajakan awal menunjukkan bahwa 11 siswa (36\%) tidak dapat menjawab soal dan sisanya menjawab soal tetapi masih ada yang mengalami masalah dalam penyelesaian soal, ditunjukkan pada lembar jawaban siswa (terlampir). Kesalahan yang ditemukan pada lembar jawaban siswa adalah siswa dalam mengerjakan soal operasi penjumlahan aljabar, dimana siswa menjumlahkan koefisien dari variabel yang berbedakemudian menyederhanakan $(11 a+14 b)$ menjadi $25 a$, sehingga hasil penjumlahan menjadi salah, seharusnya $\quad 7 a+8 a+4 b+6 b=15 a+10 b$. Kesalahan ini terjadi karena siswa belum memahami bagaimana bentuk aljabar, prinsip penjumlahan aljabar dan kurangnya ketelitian siswa.

Pada lembar jawaban diketahui siswa melakukan kesalahan dalam mengerjakan soal operasi pengurangan aljabar, dimana siswa mengurangkan koefisien dari variabel yang berbeda. Siswa mengerjakan penyederhanaan $(3 x-4 y)$ menjadi $7 x$ dan menyederhanakan $(5 x-6 y)$ 
menjadi $11 y$, kemudian menyederhanakan $7 x-11 y$ menjadi $17 x$, sehingga hasil pengurangan menjadi salah, seharusnya $3 x-5 x-4 y+6 y=-2 x+2 y$. Dari cara mengerjakan soal terlihat siswa menjumlahkan setiap suku yang ada, sedangkan operasi yang ditulis adalah pengurangan. Kesalahan ini menunjukkan bahwa siswa belum memahami prinsip pengurangan bentuk aljabar. Kesalahankesalahan yang yang dilakukan siswa menunjukkan bahwa ketidakmampuan siswa dalam memahami konsep dan memecahkan masalah yang berkaitan dengan operasi penjumlahan dan pengurangan aljabar.

Pemahaman konsep matematis siswa rendah disebabkan oleh beberapa faktor diantaranya adalah siswa tidak pernah lepas dari kesulitan yang dialami selama belajar. Siswa akan mengalami kesulitan dalam proses pembelajaran apabila perangkat pembelajaran dan proses pembelajaran tidak mampu menarik minat dan membantu siswa dalam proses pembelajaran. Berdasarkan hasil penjajakan awal menunjukkan bahwa pembelajaran di sekolah tersebut sudah menggunakan bahan ajar berupa buku ajar (paket) dan LKS. Berikut gambar LKS yang digunakan di sekolah.



sekolah

Gambar 1.1 LKS yang digunakan di

Pada gambar 1.1 diketahui bahwa LKS yang digunakan sekolah hanya memuat penjelasan singkat materi pembelajaran dan soal-soal evaluasi, tanpa memuat tentang serangkaian kegiatan pembelajaran yang dilakukan siswa dalam memahami materi pelajaran dan belum memuat contoh berupa gambar yang dapat menarik minat siswa, sehingga tidak mengarahkan siswa untuk belajar mandiri dan aktif melakukan kegiatan-kegiatan yang sesuai dengan tujuan pembelajaran, untuk memperoleh pemahaman akan materi yang dipelajari.

Effendi dan Aini (2018) mengemukakan bahwa penyajian pembelajaran matematika dengan menggunakan LKS menuntut adanya partisipasi aktif dari para siswa dan bentuk upaya yang dilakukan guru untuk membimbing siswa secara terstruktur. Ernawati, dkk (Haryonik dan Bhakti, 2017) menyatakan bahwa LKS dapat mempermudah peserta didik untuk memahami materi yang diberikan. Penggunaan LKS dalam proses pembelajaran mampu membuat siswa lebih aktif apabila LKS yang digunakan merupakan LKS yang berkualitas baik.

Untuk mengatasi masalah di atas, berdasarkan aspek LKS berkualitas baik yang belum dipenuhi, maka perlu dikembangkan LKS yang berkualitas baik yang dapat membuat siswa lebih berperan aktif dalam proses belajar mengajar. LKS yang akan dikembangkan memerlukan alternatif yang dapat membantu meningkatkan kemampuan pemahaman matematika yaitu dengan menggunakan pendekatan pembelajaran yang menempatkan siswa sebagai pusat pembelajaran.

Pembelajaran dengan menggunakan pendekatan yang mampu membuat siswa menjadi pusat pembelajaran penting digunakan, siswa menjadi aktif menemukan pemahaman konsep suatu materi dan guru sebagai fasilitator pembelajaran. Siswa juga dapat mengingat dan memahami konsep yang telah dipelajarinya apabila siswa menemukan sendiri dan belajar berdasarkan konteks kehidupan sehari-hari. Apriyani, dkk (2018) menyatakan kearifan budaya lokal dapat meningkatkan pemahaman siswa tentang aturan-aturan yang terkandung di dalam setiap kebudayaan dan memperluas wawasan siswa akan kegunaan matematika dalam kehidupan sehari-hari. Sejalan dengan itu untuk itu hasil penelitian Dazrullisa (2018) menunjukkan penerapan kearifan lokal dalam pembelajaran matematika membuat siswa aktif dan tertarik untuk melakukan pengamatan serta interaksi terhadap isi materi yang ada didalamnya dengan budaya yang menarik dan lebih riil.

Dalam kesesuaiannya dengan pendekatan Contextual Teaching and Learning (CTL), pada LKS akan disajikan konteks sebagai titik awal menemukan pemahaman konsep penjumlahan dan pengurangan bentuk aljabar, dan siswa turut aktif dalam menemukan pemahamannya dengan pengalaman belajar kontekstual terkait dengan kebudayaan seharihari.

\section{METODE PENELITIAN} Penelitian

Sebelum menyusun makalah ini, penulis Jenis 
Penelitian ini menggunakan jenis penelitian pengembangan (Research \& Development). Penelitian pengembangan bertujuan untuk mengembangkan atau menghasilkan suatu produk. Produk yang dihasilkan dari penelitian ini adalah LKS dengan pendekatan CTL untuk pemahaman konsep pada materi penjumlahan dan pengurangan bentuk aljabar untuk siswa SMP di kelas VII SMP yang valid, praktis dan efektif.

\section{Lokasi dan Subjek Penelitian :}

Penelitian ini dilaksanakan di SMP Negeri 6 Pematangsiantar yang berlokasi di Jl. Meranti Pematangsiantar. Adapun waktu pelaksanaan penelitian ini adalah pada semester ganjil T.A. 2019/2020. Subjek Penelitian dalam penelitian ini adalah siswa-siswi kelas VII-1 SMP Negeri 6 Pematangsiantar T.A. 2019/2020.

Prosedur Penelitian :

Dalam penelitian ini akan dikembangkan LKS pendekatan CTL dengan tahap pengembangan merujuk pada model pengembangan perangkat tipe 4-D, dengan batas pengembangan hingga pada tahap develop, sehingga tahapan pengembangan model 4-D yang dilakukan dalam penelitian ini adalah define, design dan develop. Pada tahap disseminate (penyebaran) tidak dilakukan mengingat penelitian pengembangan LKS ini sangat luas dan membutuhkan waktu yang lama.

Tahap Define (Pendefenisian) :

Tujuan tahap ini adalah menetapkan dan mendefinisikan syarat-syarat pembelajaran. Dalam menentukan dan menetapkan syarat-syarat pembelajaran diawali dengan analisis tujuan dari batasan materi yang dikembangkan perangkatnya. Tahap ini meliputi 5 langkah pokok, yaitu (1) Analisis ujung depan, (2) analisis siswa, (3) analisis tugas, (4) analisis konsep, dan (5) perumusan tujuan pembelajaran.

\section{Tahap Design (Perancangan)}

Tahap ini dikenal juga dengan istilah membuat rancangan. Pada tahap ini, peneliti akan membuat rancangan LKS yang memenuhi kriteria LKS yang baik. Tujuan tahap ini adalah untuk menyiapkan pengembangan perangkat pembelajaran. Dalam tahap design pada penelitian ini dilakukan penyesuaian LKS yang dikembangkan dengan pendekatan CTL. Selain itu juga dilakukan pengumpulan dan penentuan referensi buku, menyusun rancangan LKS serta menyusun perangkat penilaian dari produk yang dikembangkan.

\section{Tahap Develop (Pengembangan)}

Pada tahap pengembangan dikembangkan LKS dengan pendekatan CTL pada materi penjumlahan dan pengurangaan. Tujuan tahap ini adalah untuk menghasilkan perangkat pembelajaran yang sudah direvisi berdasarkan masukan dari pada pakar. Tahapan ini meliputi :

a).Validasi perangkat oleh para pakar diikuti dengan revisi,

b).Simulasi, yaitu kegiatan mengoperasionalkan rencana pengajaran, dan

c).Uji coba terbatas dengan siswa yang sesungguhnya.

Hasil tahap b dan c digunakan sebagai dasar revisi. Langkah berikutnya adalah uji coba lebih lanjut dengan siswa yang sesuai dengan kelas sesungguhnya.

Berdasarkan validasi ahli dan revisi, tahapan dalam proses ini dijelaskan sebagai berikut:

a).Pengembangan LKS

Pengembangan LKS sebagai berikut :

1).Bentuk media cetak,

2).Struktur LKS sesuai dengan struktur yang dianjurkan dalam Panduan Pengembangan Bahan Ajar,

3).Ditampilkan dengan lay out,

4).Disusun memperhatikan syarat kualitas kevalidan meliputi :

a).Aspek pendekatan CTL,

b).Komponen evaluasi (aspek kelayakan isi, aspek kebahasaaan, aspek sajian dan aspek kegrafisan).

LKS yang telah dikembangkan kemudian dikonsultasikan kepada dosen pembimbing, dosen ahli dan guru mata pelajaran matematika agar mendapat masukan untuk pengembangan dan perbaikan sebelum diuji cobakan.

b).Validasi ahli

Tahap ini bertujuan untuk mengetahui salah satu aspek kualitas produk pengembangan yaitu aspek kevalidan. Hal ini dilakukan dengan menguji validitas desain produk oleh ahli dan guru mata pelajaran matematika, serta mendapat saran dan kritik dari validator terhadap produk yang dikembangkan.

c).Revisi I

Data validasi yang diperoleh kemudian dianalisis dan dilakukan revisi. Produk hasil revisi merupakan pengembangan dan penyempurnaan berdasarkan validasi ahli.

d).Uji Coba 
Langkah selanjutnya adalah menguji cobakan LKS kepada siswa di kelas. Uji coba yang dilakukan adalah uji coba lapangan pada sekolah yang dijadikan subjek penelitian untuk menguji kualitas produk. Uji coba ini dilakukan di kelas VII SMP, dilakukan untuk mendapatkan data kepraktisan dan keefektifan LKS yang dikembangkan.

e).Revisi II

Setelah dilakukan uji coba, selanjutnya dilakukan revisi II sebagai penyempurnaan produk berdasarkan hasil uji coba (observasi dan respon siswa). Revisi II perlu dilakukan apabila secara praktik masih sulit digunakan oleh siswa.

Tahap Dissminate (Penyebaran)

Menurut Trianto (2009 : 192) tahap ini merupakan tahap penggunaan perangkat yang dikembangkan pada skala lebih luas misalnya kelas lain, sekolah lain, dan oleh guru lain .

\section{Instrumen Penelitian}

Instrumen digunakan dalam pengembangan untuk memenuhi kriteria kevalidan, kepraktisan dan keefektifan. Instrumen yang digunakan yaitu :

\section{Lembar Validasi LKS}

Lembar validasi ini diberikan kepada dua dosen ahli dan satu guru matematika. Instrumen ini digunakan untuk mendapatkan data para validator LKS yang disusun pada draf I sehingga menjadi bahan acuan dalam merevisi LKS dan menganalisis kevalidan LKS yang telah disusun sebelum diujicobakan. Aspek LKS yang dinilai adalah kelayakan konten (isi), Konstruk, dan Bahasa.

\section{Lembar Kepraktisan LKS}

Instrumen ini digunakan untuk memperoleh data tingkat kepraktisan perangkat pembelajaran yang dikembangkan. Lembar tersebut berupa angket yang diberikan kepada guru dan siswa sebagai pengguna LKS. Kepraktisan LKS matematika meliputi : a) Kesesuaian bahasa ,b) LKS mudah digunakan, dipahami, dan dibawa, c) Tampilan penyajian, d) kondisi dan kepuasan siswa.

\section{Lembar Tes Siswa}

Instrumen ini digunakan untuk mengumpulkan data untuk mengetahui tingkat pemahaman konsep siswa. Tes pemahaman konsep (TPK), digunakan untuk memperoleh informasi tentang kemampuan siswa terhadap topik penjumlahan dan pengurangan bentuk aljabar dan penguasaan siswa terhadap topik tersebut setelah proses pembelajaran dilakukan. Sebelum tes pemahaman konsep digunakan, perlu dilakukan ujicoba untuk mengetahui tingkat validitas, reliabilitas, daya pembeda, dan tingkat kesukaran.
Teknik Pengumpulan Data

Dalam penelitian ini data yang dikumpulkan adalah data yang dapat diperoleh dari narasumber (menggunakan sumber primer) dengan tujuan untuk dapat mengetahui apakah produk tersebut sesuai dengan kebutuhan lapangan atau tidak. Pengumpulan data dapat dilakukan dengan cara sebagai berikut :

\section{a. Teknik Tes}

Pengumpulan data melalui teknik tes dilakukan dengan memberikan instrumen tes berupa seperangkat pertanyaan/soal latihan. Soal latihan tersebut telah disediakan dalam LKS yang dikembangkan. Hal ini untuk memperoleh data mengenaik keefektivan LKS yang dikembangkan. Pengumpulan data melalui teknik tes yang dilakukan sesudah LKS yang dikembangkan dinilai valid oleh validator.

\section{b. Angket}

Pengumpulan data melalui instrumen angket dilakukan dengan memberikan instrumen berupa daftar pernyataan dan pertanyaan yang harus dijawab oleh validator. Pengumpulan data melalui angket bertujuan untuk memperoleh data mengenai aspek kevalidan dan aspek kepraktisan dari LKS yang dikembangkan. Untuk memperoleh umpan balik berupa komentar yang tepat dan sesuai, maka dipilih responden sebagai berikut : Ahli materi; dosen Matematika FKIP Universitas HKBP Nommensen Pematangsiantar, Guru matematika kelas VII SMP, dan siswa kelas VII SMP.

\section{Teknik Analisis Data}

Teknik analisis data dilakukan untuk mendapatkan produk LKS yang berkualitas baik sesuai dengan kriteria kualitas produk LKS, yaitu : valid, praktis dan efektif. Adapun langkah-langkah dalam menganalisis kriteria kualitas produk LKS yang dikembangkan tersebut sebagai berikut :

\section{a. Analisis Kevalidan}

Untuk menganalisis data validasi ahli akan digunakan analisis deskriptif dengan cara merevisi LKS berdasarkan masukan dan catatan dari validator. Tahapan ini untuk menganalisis tingkat validasi LKS yakni sebagai berikut :

a. Memberikan skor untuk setiap item dengan jawaban sangat valid (5), valid (4), cukup valid (3), kurang valid (2), sangat tidak valid (1).

b. Menjumlahkan keseluruhan skor yang diberikan oleh validator pada setiap aspek lembar validasi

c. Menghitung rata-rata setiap aspek lembar validasi dengan 
menggunakan rumus berikut : $R A_{i}=\frac{\sum_{j=1}^{n} R K_{j i}}{n}$

d. Mencocokkan nilai rata-rata total validitas (VR) yang didapat pada rumus diatas dengan kriteria kevalidan perangkat pembelajaran.

$$
\mathrm{VR}=\frac{\sum_{i=1}^{m} R A_{i}}{m}
$$

Tabel 1. Kriteria Pengkategorian Kevalidan Perangkat Pembelajaran :

\begin{tabular}{|c|c|}
\hline Interval skor & $\begin{array}{c}\text { Kategori } \\
\text { Kevalidan }\end{array}$ \\
\hline $4 \leq V R \leq 5$ & Sangat valid \\
$3 \leq V R \leq 4$ & Valid \\
$2 \leq V R \leq 3$ & Kurang valid \\
$1 \leq V R \leq 2$ & Tidak valid \\
\hline
\end{tabular}

LKS dikatakan valid jika rata-rata total validitas (VR) yang diberikan validator $\geq 3$. Jika nilai rata-rata validitas $(\mathrm{VR}) \leq 3$, maka $\mathrm{LKS}$ harus direvisi sebelum diujicobakan ketahap selanjutnya.

\section{b. Analisis Kepraktisan}

Analisis kepraktisan LKS dengan menggunakan lembar kepraktisan yang akan dinilai oleh guru bidang studi matematika dan siswa. Tahapannya :

a. Memberikan skor untuk setiap item dengan jawaban setuju (3), kurang setuju (2), tidak setuju (1),

b. Menjumlahkan keseluruhan skor yang diberikan oleh guru dan siswa untuk seluruh aspek.

c. Pemberian nilai kepraktisan dengan rumus berikut :

Nilai Kepraktisan $(\mathrm{NK})=\frac{\text { skor yang diperoleh }}{\text { skor maksimum }} \times 100$

d. mencocokkan rata-rata total kepraktisan LKS dengan kriteria kepraktisan perangkat pembelajaran.

Rata-rata total kepraktisan $=\frac{\sum_{i=1}^{n} N K}{n}$

Tabel 2. Kategori Kepraktisan Perangkat Pembelajaran

\begin{tabular}{|l|c|c|}
\hline o. & $\begin{array}{c}\text { Tingkat } \\
\text { Pencapaian }(\%)\end{array}$ & Kategori \\
\hline. & $90-100$ & $\begin{array}{c}\text { Sangat } \\
\text { Praktis }\end{array}$ \\
\hline. & $80-89$ & Praktis \\
\hline. & $65-79$ & $\begin{array}{c}\text { Cukup } \\
\text { Praktis }\end{array}$ \\
\hline & $55-64$ & $\begin{array}{c}\text { Kurang } \\
\text { Praktis }\end{array}$ \\
\hline & $0-54$ & $\begin{array}{c}\text { Tidak } \\
\text { Praktis }\end{array}$ \\
\hline
\end{tabular}

e. Perangkat pembelajaran "LKS dengan pendekatan CTL pada materi penjumlahan dan pengurangan bentuk aljabar " dikatakan praktis jika nilai yang diperoleh $\geq 80 \%$ atau minimal dalam kategori praktis.

\section{b. Analisis Efektifitas}

Analisis keefektifan LKS yakni dengan menggunakan lembar tes. Untuk mengetahui LKS dengan pendekatan CTL yang efektif maka perlu dilakukan tes. Tes dilakukan oleh peneliti dengan tujuan untuk mendapatkan nilai siswa. Tes siswa disusun sesuai dengan indikator pemahaman konsep.

Dari hasil tes siswa diperoleh rata-rata nilai yang diperoleh siswa dengan menggunakan rumus :

$$
\bar{x}=\frac{\sum_{i=1}^{n} x_{i}}{n}
$$

Setelah diketahui nilai rata-rata hasil tes siswa, maka peneliti akan menganalisis dengan menggunakan kategori penilaian sebagai berikut:

Tabel 3. Kategori hasil belajar siswa

\begin{tabular}{|l|l|}
\hline Nilai rata-rata & Kategori \\
\hline $80-100$ & Baik sekali \\
\hline $66-79$ & Baik \\
\hline $56-65$ & Cukup \\
\hline $40-55$ & Kurang \\
\hline $30-39$ & Gagal \\
\hline
\end{tabular}

Arikunto ( 2013)

LKS yang dikembangkan dikatakan efektif jika minimal nilai rata-rata siswa mencapai kategori baik. Tes hasil belajar juga bertujuan untuk mengetahui 
sejauh mana pemahaman siswa dalam belajar dengan menggunakan LKS yang dikembangkan. Nilai ini digunakan untuk mengukur keefektifan LKS.

\section{HASIL DAN PEMBAHASAN}

Berdasarkan rancangan penelitian yang telah diuraikan pada bab sebelumnya, hasil penelitian Lembar Kerja Siswa (LKS) dengan pendekatan CTL yang valid, praktis, dan efektif dengan model pengembangan 4-D yaitu Define (Pendefinisian), Design (Perancangan), Develop (Pengembangan), Disseminate(Penyebaran). Rincian dari tiap tahapan pengembangan yang telah dilaksanakan adalah sebagai berikut.

\section{1).Tahap Define (Pendefinisian)}

Tahap analisis dalam penelitian ini meliputi analisis ujung depan, analisis siswa, analisis materi, analisis tugas, dan spesifikasi indikator pembelajaran. a). Analisis Ujung Depan

Berdasarkan hasil observasi di kelas VII SMP Negeri 6 Pematangsiantar, diperoleh informasi bahwa saat proses pembelajaran matematika di kelas, pembelajaran masih berpusat pada guru, yaitu guru menerangkan dan mendemonstrasikan di depan kelas, kemudian siswa mendengarkan, mencatat, dan mengerjakan tugas sesuai apa yang diperintahkan guru. Akibatnya siswa kurang aktif dalam proses pembelajaran. Selain itu pemahaman siswa terhadap suatu materi menjadi rendah.

Bahan ajar yang digunakan dalam pembelajaran matematika adalah buku teks yang berjudul "Matematika untuk SMP/ MTs Kelas VII Semester 1" yang diterbitkan oleh Kementrian Pendidikan dan Kebudayaan Republik Indonesia 2017. Isi dari buku teks tersebut cukup lengkap dan sesuai dengan kurikulum 2013. Selain itu, dalam pembelajaran menggunakan bahan ajar yang digunakan yaitu LKS yang berasal dari penerbit, secara umum masih berisi latihan soal. Siswa terpaku hanya pada contoh-contoh soal yang terdapat pada LKS dan apabila siswa diberi soal yang berbeda, maka siswa kesulitan menjawabnya.

Oleh sebab itu, peneliti merasa perlu mengembangkan bahan ajar yang dapat membantu siswa memahami konsep serta mengorganisasikan siswa belajar agar terlibat aktif dalam merekonstruksi pengetahuan matematika melalui pemecahan masalah yang bersumber dari masalah-masalah yang dekat dengan kehidupan nyata siswa.

b).Analisis Siswa

Berdasarkan hasil observasi di kelas VII di SMP Negeri 6 Pematangsiantar didapatkan data bahwa siswa di kelas VII adalah siswa yang cukup heterogen. Hal ini dilihat dari jenis kelamin siswa yaitu 17 orang siswa perempuan dan 15 orang siswa laki-laki yang dalam proses pembelajaran juga jarang dilatih dalam mengkontruksikan pemahaman siswa. Berdasarkan perkembangan kognitif siswa SMP sudah masuk dalam tahap operasional formal, pada tahap itu siswa sudah bisa berpikir secara konseptual, sehingga dapat memikirkan beberapa hal dalam waktu yang bersamaan, termasuk hal-hal yang abstrak. Namun pada kenyataannya beberapa siswa masih belum bisa memikirkan hal yang abstrak sehingga siswa kesulitan dalam belajar matematika.

c).Analisis Materi

Analisis materi dilakukan untuk mengetahui sejauh mana materi yang akan yang akan dipelajari siswa, yaitu dengan dibuatkan peta konsep yang akan memudahkan siswa dalam memahami materi pelajaran.

\section{a. Analisis Tugas}

Pada langkah ini peneliti melakukan analisis terhadap tugas-tugas berupa kompetensi yang akan dikembangkan dalam proses pembelajaran. Kegiatan ini ditujukan untuk mengidentifikasi keterampilanketerampilan yang dimiliki oleh siswa yang akan dikembangkan dalam pembelajaran. Berdasarkan analisis siswa dan analisis konsep penjumlahan dan pengurangan bentuk aljabar, maka tugas-tugas yang dilakukan siswa selama proses pemebelajaran adalah sebagai berikut:

Tugas pada pokok materi penjumlahan dan pengurangan bentuk aljabar dalam LKS:

1. Menjelaskan bentuk aljabar dan melakukan operasi penjumlahan dan pengurangan bentuk aljabar

2. Menyelesaikan permaslahan yang berkaitan dengan operasi penjumlahan dan pengurangan bentuk alajabar

\section{b. Spesifikasi Indikator Pembelajaran} Indikator atau tujuan pembelajaran disesuaikan dengan kompetensi inti dan kompetensi dasar sesuai dengan kurikulum 2013. Adapun indikator pembelajaran kompetensi yang akan dicapai siswa yaitu:

1. Mengenal bentuk alajabar.

2. Mengidentifikasi unsur-unsur bentuk aljabar

3. Menyajikan permasalah nyata dalam bentuk aljabar

4. Menyelesaikan operasi penjumlahan bentuk aljabar

5. Menyelesaikan operasi pengurangan bentuk aljabar 
6. Menyajikan permasalah nyata pada penjumlahan dan pengurangan bentuk aljabar

7. Menyelesaikan permasalahan kontekstual pada penjumlahan dan pengurangan bentuk aljabar

\section{1).Tahap Design (Perancangan)}

Setelah dilakukan analisis kebutuhan dan pemilihan materi, selanjutnya membuat perencanaan. Adapun rancangan struktur format LKS yang dikembangkan adalah sebagai berikut: Sampul LKS, judul LKS, Petunjuk LKS, Kompetensi Inti, Kompetensi Dasar, dan Tujuan Pembelajaran, Kolom identitas yang berisi nama kelompok dan nama anggota, Aktivitas yang berisi kegiatan dari LKS, Kesimpulan yang berisi hasil setiap aktivitas yang dilakukan siswa, Evalusi yang berisi latihan untuk dikerjakan tiap siswa sebagai penerapan dari konsep yang ditemukan.

\section{2).Tahap Develop(Pengembangan)}

Tahap pengembangan dalam penelitian ini meliputi pengembangan pada tahap perancangan sebelumnya. Rancangan atau draft 1 LKS disusun sesuai urutan penyajian materi. Pengembangan LKS memuat tahapan dalam pendekatan CTL kemudian LKS divalidasi oleh ahli untuk selanjutnya mendapat penilaian, masukan, dan saran. Peneliti kemudian memperbaiki dan merevisi LKS berdasarkan masukan dan saran dari ahli.Rincian dari masingmasing kegiatan pada tahap pengembangan LKS adalah sebagai berikut.

a). Pengembangan Perancangan

Pada tahap ini, peneliti mengembangkan rancangan sebagai LKS draft 1 pada tahap desain. Selanjutnya draft tersebut dikonsultasikan kepada dosen pembimbing dengan tujuan untuk mendapatkan saran perbaikan dan penyempurnaan. Draft yang telah dikonsultasikan tersebut selanjutnya direvisi sesuai saran dosen pembimbing, kemudian dikonsultasikan kembali hingga draft tersebut disetujui untuk divalidasikan kepada ahli.

\section{b).Validitas LKS}

LKS divalidasi kepada dosen ahli. Produk hasil pengembangan yang telah divalidasi oleh 2 dosen ahli dan 1 guru matematika kelas VII, selanjutnya akan dijadikan acuan untuk melakukan perbaikan secara teoritik terhadap produk hasil pengembangan. Data yang diperoleh dari penilaian ahli sebagai berikut:

Tabel 4. Hasil Analisis Data Lembar Validasi

\begin{tabular}{|c|c|c|c|c|}
\hline \multirow[t]{2}{*}{ No. } & \multirow{2}{*}{\multicolumn{2}{|c|}{ Aspek yang }} & & \multirow[t]{2}{*}{ Kriteria } \\
\hline & & i Skor & & \\
\hline \multirow[t]{2}{*}{1.} & & Content (isi) & & Sangat \\
\hline & 4,28 & & Valid & \\
\hline \multirow[t]{2}{*}{2.} & & Konstruk & & Sangat \\
\hline & 4,4 & & Valid & \\
\hline \multirow[t]{3}{*}{3.} & & Bahasa & & Sangat \\
\hline & 4,5 & & Valid & \\
\hline & & Rata-rata & & \\
\hline
\end{tabular}

c). Revisi LKS

Sebelum perangkat diimplementasikan, peneliti melakukan perbaikan terlebih dahulu terhadap LKS yang sudah melalui tahap validasi. Peneliti melakukan perbaikan atau revisi berdasarkan komentar dan saran ahli pada tahap validasi sebelumnya.

\section{a. Tahap Uji Coba (Implementasi)}

Setelah LKS dinyatakan layak untuk diujicobakan dan telah direvisi sesuai saran dan masukan dari validator, kemudian diimplementasikan dalam kegiatan pembelajaran. Uji coba pembelajaran menggunakan LKS dengan pendekatan CTL dilaksanakan di SMP Negeri 6 Pematangsiantar tanggal 24 agustus 2019 hingga 31 agustus 2019 terhadap siswa kelas VIII-4. Guru matematika SMP Negeri 6 Pematangsiantar memberikan kesempatan untuk melakukan penelitian sebanyak 3 kali pertemuan dalam kelas.

Pertemuan tersebut digunakan peneliti untuk melakukan kegiatan pembelajaran dengan LKS, kemudian setelah pembelajaran dengan LKS telah selesai siswa diberikan angket untuk megetahui kepraktisan LKS dan diberikan juga tes hasil belajar siswa untuk mengetahui tingkat keefektifan LKS tersebut. Tabel berikut merupakan tabel waktu pelaksanaan ujicoba produk.

b. Hasil uji coba di SMP Negeri 6 Pematangsiantar adalah sebagai berikut:

1. Analisis Data Kepraktisan Penggunaan LKS dalam Pembelajaran

Analisis data kepraktisan penggunaan LKS pada materi penjumlahan dan pengurangan bentuk aljabar untuk siswa kelas VII dengan pendekatan CTL didasarkan pada hasil penilaian kepraktisan LKS di SMP Negeri 6 Pematangsiantar.

Berdasarkan hasil analisis data kepraktisan LKS tersebut dapat disimpulkan bahwa LKS mudah digunakan, dipahami, dan dibawa, memiliki kegunaan untuk membantu siswa dalam memahami materi serta minat siswa untuk belajar penjumlahan dan pengurangan bentuk aljabar. 
Berdasarkan komentar dan saran siswa pada lembar kepraktisan LKS tersebut dan dari hasil perhitungan nilai kepraktisan, maka LKS dengan pendekatan CTL pada materi penjumlahan dan pengurangan bentuk aljabar dalam kategori praktis dengan rata-rata kepraktisan 83,3 \% berdasarkan tabel kategori kepraktisan perangkat pembelajaran yaitu $83,3 \% \geq$ 80\% LKS kategori praktis.

2. Analisis Data Keefektifan LKS dalam Pembelajaran

Berdasarkan hasil analisis tes siswa diketahui bahwa nilai rata-rata siswa kelas VII SMP Negeri 6 Pematangsiantar sebesar 79,1. Berdasarkan kategori yang terdapat di bab III bahwa nilai rata-rata siswa $\geq 75$ termasuk kedalam kategori baik sehingga dapat disimpulkan bahwa LKS yang dikembangkan efektif untuk digunakan dalam proses pembelajaran.

\section{KESIMPULAN}

Berdasarkan hasil penelitian dan pembahasan terhadap LKS yang dikembangkan, dapat disimpulkan sebagai berikut :

1. Proses pengembangan LKS dengan pendekatan CTL pada materi penjumlahan dan pengurangan bentuk aljabar dikembangkan dengan 4 tahap, yaitu Define (Pendefinisian), Design (Perancangan), Develop (Pengembangan).

2. Hasil pengembangan LKS dengan pendekatan CTL pada materi penjumlahan dan pengurangan bentuk telah valid berdasarkan isi, kontruk dan bahasa dengan tingkat kevalidan 4,33 dalam kategori sangat valid berdasarkan kriteria kevalidan perangkat pembelajaran yaitu $4 \leq V R<5$ kategori valid.

3. Hasil pengembangan LKS dengan pendekatan CTL pada materi penjumlahan dan pengurangan bentuk telah praktis dengan tingkat kepraktisan 83,30\% dalam kategori praktis berdasarkan kategori kepraktisan perangkat pembelajaran yaitu $80 \% \quad-90 \%$ kategori praktis.

4. Hasil pengembangan LKS dengan pendekatan CTL pada materi penjumlahan dan pengurangan bentuk telah efektif berdasarkan hasil tes siswa dengan nilai rata-rata siswa 79 dalam kategori baik berdasarkan kategori hasil belajar siswa yaitu 66-79 kategori baik.

\section{DAFTAR PUSTAKA}

Apriyani, Dwi Sari, Linda Yustika, dan Nurmah, Elok. 2018. Keaktifan dan Kreatifitas dalam Belajar Matematika dengan Mengenali Kearifan Budaya Lokal. Prosiding Semandik Pekalongan: Universitas Pekalongan.

Arikunto, Suharsimi. 2010. Dasar-Dasar Evaluasi Pendidikan (Edisi Revisi) Jakarta: Bumi Aksara.

Effendi, N.S. Kiki, \& Aini. Indie Noor, 2018. Pelatihan Penyusunan Lembar Kerja Siswa (LKS) Bagi Guru Matematika SMP di Telukjambe Karawang. Jurnal Pengabdian Masyarakat, Vol 3 (1).

Depdiknas, 2006. Peraturan Departemen Pendidikan Nasional Tentang Panduan Pengembangan Bahan Ajar Tahun 2008. Jakarta: Depdiknas.

Dazrullisa, 2018. Pengaruh Pembelajaran Matematika Berbasis Kearifan Lokal terhadap Minat Belajar Siswa. Jurnal Pendidikan Matematika Vol 9(2). 